http://dx.doi.org/10.4314/jae.v15i1.7

\title{
Impact of National Fadama Development Project II on Rice farmers' profitability in Kogi State, Nigeria
}

\author{
Olaolu M.O., Ajayi A.R. and Akinnagbe O.M. \\ Department of Agricultural Extension, \\ University Nigeria Nsukka, Nsukka, Nigeria. \\ E-mail: michealolaolu@yahoo.com
}

\begin{abstract}
This study examined the impact of National Fadama Development Project II on the profitability of rice farmers and assessed the extent to which the various innovations disseminated by the project were adopted by the rice farmer beneficiaries. The project which had all operating expenses cofinanced by the various key stakeholders also used community driven development (CDD) approach in extension service delivery. The study made use of primary data collected with the aid of interview schedule. The analytical tools used included descriptive statistics, adoption index and gross margin analysis (GM). The study employed the before and after model to determine the impact of the project on farmers profitability. The adoption index for rice production facilities, rice farming inputs and land preparation / planting distance were 0.34, 0.84 and 0.96, respectively. This implied that the farmers' adoption of the various rice production facilities was 34\%, while rice farming inputs had $84 \%$ adoption level, and the various technologies on rice field preparation had $96 \%$ adoption level. Weeding was the rice farming activity with the highest cost, $N$ 1,210:40 and N 1,690:50 for the years 2003 and 2009, respectively. The percentage gross margins per 0.5 ha of rice farm were $26.9 \%$ and $81.4 \%$ for before and after respectively which implied that fadama rice farmers had higher profitability as a result of the farmers' participation in the project.
\end{abstract}

Keywords: Profitability, Fadama, Kogi state and community driven development

\section{INTRODUCTION}

Rice is an important staple crop in Nigeria. Its cultivation, processing and marketing offer employment opportunities for farm and non-farming households. Since the early 1960s, the West Africa Rice Development Association (WARDA) has made several efforts focused on achieving self-sufficiency in rice production in West Africa, and thus, eliminating dependence on rice imports from outside the region (Olubanjo and Oyebanjo 2005). Nonetheless, a wide gap continues to exist between domestic rice supply and demand in the region, and more particularly, in Nigeria. As a consequence, imported rice has continued to be sourced yearly to 
supplement domestic production. The market for domestic rice have been shrinking due to rice imports leading to low capacity utilization at the small local rice mills and the migration of the active farm population away from the farms to seek alternative employment in the cities. The proportion of local rice available in Nigerian markets is far less than that of imported rice and there has been a rise in intra regional trade for local rice supplies. The sourcing of paddy rice especially by small millers have shifted to other sources (Ezedinma ,Undated). The general wage levels in villages are negatively associated with productivity of rice among other crops and profitability of rice and pepper (Nkonya, Pender, Kato, Oni, Phillip and Ehui, 2010).

The rice import bill for Nigeria, which was N123.61 million in 1980 (Okorji and Onwuka, 1994), rose to N9.72 billion in the year 2000 (FOS, 2001). In 2002, Nigeria even ranked among the top six largest world rice importers with total milled rice import put at 1,251,718 tonnes (Anon., 2004). Also in 2004 volume of imported was 0.84 million metric tons but the price was N30.31billion. This position could be attributed to the high tariff wall of $150 \%$ (Biyi, 2005).

Over the years, the crop has witnessed a steady increase in demand and its growing importance is evident given its important place in the strategic food security planning of Nigeria (Shehu, 2010). Hence, there is need to improve its production. In a bid to improve production of agriculture several programmes were embarked upon by both past and present government of Nigeria among which was the National Fadama Development Project phase (II) (NFDP-II) or Fadama II project. Fadama is a Hausa language word which means wetland. Fadama is a land which is flooded in the wet season. Water dominates this environment probably because water is near the earth surface land or because the land is covered by shallow waters. World Bank (2001) defined fadama as river valley areas which are seasonally flooded or have high water tables for all, or a large part of the year. Fadama are flood plains and low lying areas underlined by shallow aquifers found along Nigeria's river system. The NFDP-II was designed to assist some States of the Federation through the World Bank and African Development Bank supported Agricultural Development Programme (ADP) network to, among others: finance the provision of shallow tube wells in Fadama lands for small scale irrigation, simplifying drilling technologies for shallow tube wells, organizing fadama farmers for irrigation management, and other services (Ayanwale and Alimi, 2004). It is believed that the provision of this facility should not only boost agricultural production but enhance the income of the farmers and thereby lift them out of the vicious circle of poverty (Adeolu and Taiwo 2004).

The Kogi State NFDP-(II) was negotiated and signed on the 12th December, 2003. It became loan effective and disbursement effective on 3rd May, 2004 and 26th July, 2005, respectively (KOGI ADP-SFDO, 2007). The project which had all operating expenses co-financed by the various key stakeholders also used the community driven development (CDD) approach in their extension service delivery (KOGI ADP-SFDO, 2007). The project in Kogi State came as a result of the baseline survey on the project which revealed that the annual income from crop production as a primary occupation was on the average, N103,568:00 
as at 2003. These results of the baseline study made the State one of the States in need of an intervention (Fadama Development Office FDO, 2006).

At the end of the project life cycle, it was expected that introduction of sustainable land management practices that would reduce land degradation normally caused by deforestation, bush burning and pollution and increase the income of the rural farm families, will be achieved among other project targets (KOGI ADP-SFDO, 2007).

According to the Kogi State ADP-SFDO (2007), some improved rice agronomic practices had been disseminated and the rice farmers responded favourably. Under fadama programme in Kogi state, intensive efforts had been made for the past six years to bring about the expected improvement in rice productivity for the purpose of enhancing the income level among the rice farmers and at the same time, sustaining their socio-economic life.

\section{Purpose of the Study}

1. determine the adoption level of the various technologies in rice production under the NFDP-II; and

2. the profitability of rice production among beneficiaries as well as the impact of the NFDP-II on their profitability.

\section{METHODOLOGY}

The study was carried out in Kogi State. The State lies on latitude 71' $49^{\circ}$ North and longitude $61^{\prime} 45^{\circ}$ East with a geological feature depicting young sedimentary rocks and alluvium along the riverbeds, which promotes agricultural activities and has an average maximum temperature of $33.2^{\circ} \mathrm{C}$ and average minimum of $22.8^{\circ} \mathrm{C}$. It shares common boundaries with Niger, Kwara, Nassarawa and The Federal Capital Territory to the north. To the east, the State is bounded by Benue State, to the south by Enugu and Anambra States, and to the west by Ondo, Ekiti and Edo States. Ethnically, Igala, Yoruba, Egbira, Nupe and Bassa form the main ethnic groups. Kogi State occupies 29,833 square kilometers and has a population of 3,314,043 out which 1,672,903 are male and 1,641,140 female (NPC, 2007). The State has two distinct weather the dry season, which lasts from November to February and rainy season that lasts from March to October. Annual rainfall ranges from $1016 \mathrm{~mm}$ to $1524 \mathrm{~mm}$ (www.kogistatenigeria/aboutus.org).

A multistage sampling technique was used. In stage one, 4 LGAs were purposively selected out of the 10 LGAs that participated, this was based on their involvement in rice production. The LGAs were Idah, Ibaji, Lokoja and Kogi. The second stage involved collection of the list of communities that were involved in the Fadama rice production from each of the LGAs. From that list two communities were selected through simple random sampling technique. A total of eight communities were involved in the study. The third stage involved the collection of lists of participant in each of the eight communities. From the list, a total of fourteen rice farmers were selected through simple random sampling technique. 
Thus a total of 112 farmers were interviewed for the study. Data were collected using interview schedule.

The socio economic characteristics of the respondents were analysed using frequency, percentage and mean. The adoption levels of the various innovations (practices, systems and technologies) introduced to the rice farmers by the Kogi state FDP-II, were placed on a 5-point Likert type adoption scale was used where the farmers were asked to indicate their adoption stage on the 5-point adoption scale. Their response categories and the corresponding weighted values were as follows: Aware $=1$, Interest $=2$, Evaluation $=3$, Trial $=4$ and Adoption $=5$. The adoption index was calculated as follows: Computation of total adoption score per innovation. This was by adding up all the various adoption scores. Computation of the total mean (M) adoption score per innovation. This was computed by dividing the total adoption score by the number of respondents involved. Computation of the grand mean $(\mathrm{M})$ adoption score. This was calculated by adding all the total mean adoption scores and dividing them by the number of innovations considered. Computation of the adoption index. This was carried out by dividing the grand mean (M) adoption score by 5 (i.e. the 5 -stages of adoption). The profitability of fadama rice production was measured by requesting all the various variable cost of rice production by farmer per plot of land (0.5ha) and the revenue gotten per plot of 0.5 ha of each of the rice farmers. Profitability was measured using gross margin (GM) analysis. The GM analysis was carried out as follows:

$\mathrm{GM}=\mathrm{TR}-\mathrm{TVC}$, Where $\mathrm{GM}=$ rice production gross margin, $\mathrm{TR}=$ Total revenue from sale of rice produced from a plot (0.5ha) of farm in naira. TVC = Total variable cost of the average operating inputs and labour in naira per plot in naira.

Percentage margin is given by $\% \mathrm{GM}=\frac{\mathrm{GM}}{\mathrm{TVC}} \mathrm{X} \frac{100}{1}$

\section{RESULTS AND DISCUSSION}

\section{Socio-economic Characteristics}

The results on the socio-economic characteristics of the respondents showed that the majority of the farmers $(51.8 \%)$ were males, and the mean age of the farmers was 45.5 years. Majority $(76.8 \%)$ of the farmers were married. The educational levels revealed that most of the respondents had one form of formal education with about $87 \%$. The mean household size of the farmers and facilitators were 11 persons. The mean years of farming experience of the farmers was about 28 years. The results also from Table 1 show that most of the respondents $(55.4 \%)$ were Christians, while the majority $(57.1 \%)$ of the farmers had farming as their primary occupation. Information from fellow farmers was the most popular (96.4\%) source of information on fadama programme. 


\section{TABLE 1: Distribution of the respondents by socio-economic} characteristics

\begin{tabular}{|c|c|c|}
\hline \multirow[t]{2}{*}{ Variable } & \multicolumn{2}{|c|}{ Farmers $(\mathrm{N}=112)$} \\
\hline & $\%$ & Mean(M) \\
\hline \multicolumn{3}{|l|}{ Sex } \\
\hline Male & 51.8 & \\
\hline Female & 48.2 & \\
\hline Age (years) & & 45.5 \\
\hline $20-29$ & 7.2 & \\
\hline 30-39 & 12.6 & \\
\hline $40-49$ & 42.9 & \\
\hline $50-59$ & 29.5 & \\
\hline \multirow{2}{*}{\multicolumn{3}{|c|}{ Marital status }} \\
\hline & & \\
\hline Single & 6.2 & \\
\hline Married & 76.8 & \\
\hline Widowed & 13.4 & \\
\hline Divorced & 3.6 & \\
\hline \multicolumn{3}{|l|}{ Educational level } \\
\hline No formal education & 13.4 & \\
\hline Primary school attempted & 5.4 & \\
\hline Primary school completed & 16.1 & \\
\hline Secondary school attempted & 17.0 & \\
\hline Secondary school completed & 29.5 & \\
\hline OND/NCE & 13.4 & \\
\hline HND/First degree & 4.5 & \\
\hline \multirow{2}{*}{\multicolumn{3}{|c|}{ Religion }} \\
\hline & & \\
\hline Christianity & 55.4 & \\
\hline Islam & 44.6 & \\
\hline \multicolumn{3}{|l|}{ Household size } \\
\hline $1-5$ persons & 8.0 & 10.6 \\
\hline 6-10 persons & 58.0 & \\
\hline $11-15$ persons & 16.1 & \\
\hline $16-20$ persons & 10.7 & \\
\hline 21-25 persons & 4.5 & \\
\hline Above 25 persons & 2.7 & \\
\hline \multicolumn{3}{|c|}{ Years of farming/working experience } \\
\hline $6-15$ years & 12.5 & \\
\hline $16-25$ years & 30.4 & 27.7 \\
\hline $26-35$ years & 38.4 & \\
\hline $36-45$ years & 16.1 & \\
\hline $46-55$ years & 2.7 & \\
\hline \multicolumn{3}{|l|}{ Primary occupation } \\
\hline Civil service & 27.7 & \\
\hline Farming & 57.1 & \\
\hline Trading & 10.7 & \\
\hline Fishing & 4.5 & \\
\hline \multicolumn{3}{|c|}{ Sources of information on Fadama programme } \\
\hline Radio & 86.6 & \\
\hline Television & 59.8 & \\
\hline Friends/Neighbour & 92.9 & \\
\hline ADP/ Ministry of agriculture & 88.4 & \\
\hline Family members & 59.8 & \\
\hline Fellow farmers & 96.4 & \\
\hline Buyers & 7.1 & \\
\hline Fadama facilitator & 93.8 & \\
\hline
\end{tabular}

Source Field survey 2010.

*Multiple responses 


\section{Adoption of Improved Rice Production Technologies among Fadama (II) Beneficiaries}

Rice production facilities: The result in Table 2 shows among some of the improved rice production innovations introduced by the NFDP(II), only the rice farming inputs and field preparation/planting distance had above $50 \%$ adoption ratio with adoption index of 0.84 and 0.96 respectively. Rice production facilities had an adoption index of 0.34 , showing that only rice production facilities were below average.

Rice farming inputs: It is evident from Table 2, that the grand mean was 4.2. The implication of this grand mean was that the farmers were at the trial stage on the 5 -point adoption scale. This also could be as a result of the subsidies made available to the beneficiaries of the fadama development programme which made it easier for them to source rice farming inputs. The adoption index of 0.84 from the rice farming inputs innovations meant that the farmers were above average in the adoption of the various rice farming inputs. The high adoption could be as a result of the subsidies on each of the farm inputs given to the beneficiaries as well as the fact these farm inputs were given to the farmers as loans which were to be repaid repay back after harvesting their farm produce.

Field preparation/ planting distance: Harrowing, ploughing, as well as 25 by 25 planting space had adoption mean scores of $4.7,4.6$, and 5.0 respectively. These findings implies that all the field preparation/planting distance technologies among the beneficiaries were adopted. The field preparation / planting distance had a grand mean of 4.8 on a 5-point adoption scale. This implied that with regard to the field preparation/ planting distance the farmers were at a full adoption stage on the same 5-point adoption scale. Field preparation / planting distance technologies had an adoption index of 0.96 . This index shows that the various technologies on field preparation/ planting distance were far above average in its adoption. This index shows a very high adoption. This could be as a result of the closeness of these practices to already existing rice farming practices the farmers were used to. 
TABLE 2: Distribution of farmers' adoption of improved rice technologies $(\mathrm{N}=112)$

\begin{tabular}{|c|c|c|c|c|c|c|c|}
\hline \multirow[b]{2}{*}{ Innovations } & \multicolumn{7}{|c|}{ Adoption Levels/ adoption scores } \\
\hline & 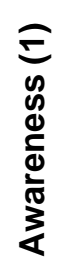 & 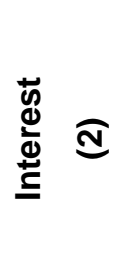 & 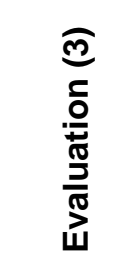 & 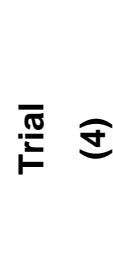 & $\stackrel{\frac{0}{2}}{\frac{0}{0}}$ & 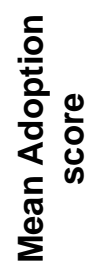 & 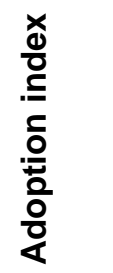 \\
\hline \multicolumn{8}{|l|}{$\begin{array}{l}\text { Rice production } \\
\text { facilities }\end{array}$} \\
\hline Tube well & 93 & 12 & 15 & 28 & 5 & 1.4 & \\
\hline Bore holes & 34 & 3 & 44 & 20 & 294 & 3.5 & 0.34 \\
\hline Rice dis-stoner & 38 & 0 & 0 & 0 & 0 & 0.3 & \\
\hline \multicolumn{8}{|c|}{ Rice farming inputs } \\
\hline Improved variety & 2 & 2 & 66 & 4 & 430 & 4.5 & \\
\hline NPK fertilizer & 1 & 2 & 6 & 8 & 530 & 4.9 & \\
\hline Orizo plus alone & 13 & 2 & 27 & 4 & 440 & 4.3 & 0.84 \\
\hline Buta star alone & 9 & 70 & 36 & 24 & 250 & 3.5 & \\
\hline Herbicide mixture & 19 & 14 & 9 & 88 & 305 & 3.9 & \\
\hline \multicolumn{8}{|l|}{$\begin{array}{l}\text { Field preparation/ } \\
\text { planting distance }\end{array}$} \\
\hline Harrowing & 9 & 4 & 0 & 0 & 510 & 4.7 & \\
\hline Ploughing & 9 & 4 & 0 & 12 & 490 & 4.6 & 0.96 \\
\hline $\begin{array}{l}\text { The } 25 \text { by } 25 \\
\text { planting method }\end{array}$ & 1 & 0 & 0 & 0 & 555 & 5.0 & \\
\hline
\end{tabular}

Source: Field survey 2010

\section{Profitability of rice production among fadama (II) beneficiaries}

Variable cost: The analysis on the variable cost on Table 3 revealed that the total variable cost for rice production per 0.5 ha before the programme was N23,954:00, and N39,760:00 after. These variables considered were the average operating inputs and labour. This variable cost is made up of the various inputs such as 
seeds, herbicides, fertilizers. Among these various inputs, the cost of the fertilizer applied to the farms was the highest (N3,068.8 and N2,500)in both year 2003 and 2009 respectively. The demand for this fertilizer shows that low soil fertility was a case with most farmers for which they needed to improve upon. The various farming labour that was part of what mades up the total variable cost included wedding, fertilizer application, harvesting, handling, threshing and etc. Weeding was the rice farming activity with the highest cost (N1,210:40 and N1,690:50) for the years, 2003 and 2009 respectively. Rice handling had the least cost to contribute to the total variable cost. The contribution from rice handling was on the average $\mathrm{N} 12.5$ as at 2003 and N 15.4 in the year 2009. The absence of unit cost and quantities for threshing and bird scaring was because of the much varying unit cost and because several farmers do farming activities themselves.

Revenue: Table 3 shows that the revenues of the sales from rice produced per 0.5 ha before and after. The revenue in the year 2003 was N30,403.50 while $\mathrm{N} 72,115.00$ was the revenue for 2009. This result shows that the rice farmer beneficiaries made higher revenue from their rice production after the project than before. This implied that the project made a positive impact on the rice farmers' revenue which invariably meant higher income for the farmers.

Gross margin: As a result of the total variable cost - revenue interaction in Table 3 , the result in Table 3 shows a profit margin of N 6,449.50 before and N32,355:00 after. The percentage gross margins were $26.9 \%$ and $81.4 \%$ for before and after respectively. It can also be observed that there is a higher profit margin after the programme started than before. The results agree with that of Nwalieji, (2006) who concluded that participation in programmes such as fadama development programmes results in increased production profitability after/during the programme life. Also Akande (2003) was of the opinion that rice production has been found to be quite profitable in Nigeria and however, domestic rice was not as profitable as it would have been if there were no stiff competitions from imported rice. This implied that the fadama rice farmers under this study had better profitability as a result of their participation in the fadama development programme. It could therefore be concluded that the programme has made a meaningful impact on rice production and income of the beneficiaries.

Impact of fadama (II) on rice profitability: The result on the difference between rice farmers' profitability before and after the project shows that there was significant difference in the farmers' profitability before and after the project. The tvalue will be positive if the first mean is larger than the second and negative if it is smaller. This result indicated a negative t-value which implied that mean of the rice farmers' profitability was smaller before than it was after. This further implied that there was more profit after the project than before, meaning that the project improved the profitability of rice farmer beneficiaries. 
TABLE 3: Profitability of fadama (II) rice production per 0.5 ha plot of land

\begin{tabular}{|c|c|c|c|c|c|c|c|}
\hline \multirow[t]{2}{*}{ Item/ operation } & \multirow[t]{2}{*}{ Unit } & \multicolumn{3}{|c|}{ Year 2003} & \multicolumn{3}{|c|}{ Year 2009} \\
\hline & & $\begin{array}{l}\text { Qty } \\
\text { (M) }\end{array}$ & $\begin{array}{c}\text { Unit } \\
\text { price } \\
\text { M) }\end{array}$ & $\begin{array}{l}\text { Total } \\
(\mathrm{M})(\mathrm{N})\end{array}$ & $\begin{array}{l}\text { Qty } \\
\text { (M) }\end{array}$ & $\begin{array}{c}\text { Unit } \\
\text { Price } \\
(\mathrm{M})\end{array}$ & $\begin{array}{c}\text { Total (N) } \\
(\mathrm{M})\end{array}$ \\
\hline \multicolumn{8}{|l|}{ Variable cost: } \\
\hline Rice seed & Bags & 0.1 & 1,821 & 182.1 & 0.2 & 5000 & 806.8 \\
\hline Fertilizer applied on rice & Bags & 2 & $3,068.8$ & 6137.5 & 3.3 & 2,500 & 8135.7 \\
\hline Herbicides ( Orizo) applied & Liter & 1.8 & 1,000 & 1867.4 & 2.6 & 1,200 & 3174.6 \\
\hline Herbicides (Buta) applied & Liter & 0.4 & 945 & 377.7 & 1.1 & 1,100 & 1236.6 \\
\hline Field cultivation for rice & Man-day & 3 & 828.3 & 2484.8 & 3 & 1,106 & 3320.5 \\
\hline $\begin{array}{l}\text { Weeding of rice } \\
\text { Labour for fertilizer }\end{array}$ & Man-day & 3 & $1,210.4$ & 3631.2 & 3 & $1,690.5$ & 5071.4 \\
\hline application for rice & Man-day & 3 & 226.8 & 680.4 & 3 & 544.6 & 1633.9 \\
\hline Harvesting of rice & Man-day & 3 & 822.2 & 2466.6 & 3 & $1,217.3$ & 3651.8 \\
\hline Handling of rice & Man-day & 3 & 4.20 & 12.5 & 3 & 15.4 & 46.3 \\
\hline Transportation for rice & Man-day & 15 & 79.9 & 1197.8 & 32.1 & 100 & 3210.7 \\
\hline production & Man-day & 10.8 & 69.8 & 753.5 & 14.2 & 100 & 1423.6 \\
\hline Bagging of rice & Man-day & 0 & 0 & 485.7 & 0 & 0 & 774.0 \\
\hline Threshing & Man-day & 0 & 0 & 716.1 & 0 & 0 & 1492.0 \\
\hline $\begin{array}{l}\text { Bird scaring } \\
\text { Rice farming implements } \\
\text { Total Variable cost }\end{array}$ & Number & 0 & 0 & $\begin{array}{l}3962.5 \\
23,954.0\end{array}$ & 0 & 0 & $\begin{array}{l}4200.0 \\
39,760.0\end{array}$ \\
\hline $\begin{array}{l}\text { Total revenue from rice } \\
\text { production }\end{array}$ & & & & $30,403.5$ & & & $72,115.0$ \\
\hline
\end{tabular}

\begin{tabular}{lllllllll}
$\frac{\text { Summary }}{\text { Total }}$ & Total \\
revenue (N) & G.M. (N) & $\begin{array}{l}\text { \% } \\
\text { cost } \\
\text { (N) }\end{array}$ & & $\begin{array}{l}\text { Total } \\
\text { margin } \\
\text { revenue }\end{array}$ & $\begin{array}{l}\text { Total } \\
\text { cost (N) }\end{array}$ & $\begin{array}{l}\text { G.M. } \\
(\mathbf{N})\end{array}$ & $\begin{array}{l}\% \\
\text { margin }\end{array}$ & t-value \\
$30,403.5$ & 23,954 & $6,449.5$ & 26.9 & 72,115 & 39,760 & 32,355 & 81.4 & $-14.94^{*}$ \\
\hline
\end{tabular}

${ }^{*}$ Significant $(P \leq 0.05)$

\section{CONCLUSION AND RECOMMENDATIONS}

This study has shown clearly that technologies on farm field preparation/ distance of planting and the various innovations on rice farming inputs had very high adoption index of 0.84 (84\% adoption) and $0.96(96 \%$ adoption) respectively which showed high rate of adoption by the farmers. The beneficiaries had higher profitability on their rice production during the programme than before the commencement of the programme. This suggested that the project positively impacted on the incomes and profitability of the rice farmers who benefited from the project, consequently improved their livelihoods.

The following policy recommendations are hereby deemed appropriate. Given the fact that agricultural production operation are time-bound, the timely, adequate and consistent provision of farming inputs and fadama facilities such as 
improved seeds, fertilizers, herbicides, tube-wells, rice dis-stoner etc. at subsidized cost by the NFDP(II) management. This will enhance rice production in the area. Seeing that projects of these sorts are enhancing the income of the farmers, more of these programmes should be embarked upon as to develop agriculture in Nigeria.

\section{REFERENCES}

Adeolu, B.A. and Taiwo, A. (2004). The Impact of national Fadama facility in alleviating rural poverty and enhancing agricultural development in southwestern Nigeria. Journal of Social Science, 9(3): 03-128.

Akande, T. (2003) An Overview of the Nigerian Rice Economy an online paper retrieved on the 13th of October 2010.www.nigeriaonline/nigerieneconomy.org.

Anon., 2004. Rice: a success story for some. CTA Spore 115, 4-5.

Ayanwale, A.B. Alimi, T (2004).The Impact of Agricultural Development Project (ADP) in Nigeria. J. Soc. Sci., 9(3): 157-161.

Biyi D. (2005). Government policies and competitiveness of Nigerian rice economy. Paper presented at the 'Workshop on Rice Policy \& Food Security in Sub-Saharan Africa' organized by WARDA, Cotonou, Republic of Benin, November 07-09,

Ezedinma, C (Undated) Impact of Trade on Domestic Rice Production and the challenge of Selfsufficiency in Nigeria a paper presented at International Institute of Tropical Agriculture Ibadan.

Federal Office of Statistics (FOS), 2000. Annual Abstracts of Statistics. Lagos, Nigeria.

KOGI ADP-SFDO(2007) State fadama development project in kogi state "poverty reduction and increased productivity through empowerment" a bulletin of the SFDO Kogi state.

National Population Commission, (NPC) (2007). Population figure. Federal republic of Nigeria, Abuja. Retrieved from http://www.npc.gov

Nkonya, E. Pender, J. Kato,E. Oni O. Dayo P. Ehui, E (2010) Nigeria Strategy Support Program IFPRI Brief No. 19

Nwalieji, A.H. (2005). Evaluation of Fadama phase-(I) vegetable production project of the Anambra State Agricultural Development Programme an M.Sc. research findings seminar presented to the department of Agricultural extension University of Nigeria Nsukka.

Okorji, E.C. and Onwuka, K.O. 1994, A Comparative Analysis of Costs and Returns of Non-irrigated and Irrigated Rice Production Systems in UzoUwani Local Government Area of Enugu State, Nigeria. Journal of The West African Farming Systems Research Network 4(2), pp 12-19. 
Olubanjo O.O. and Oyebanjo,O. (2005), Determinants of profitability in rain-fed paddy rice production in Ikenne Agricultural Zone, Ogun State, Nigeria in African Crop Science Conference Proceedings, Vol. 7. pp. 901-903

Shehu, J.F. (2010). Production efficiency differentials and innovative behavior among rice farmers in northeastern Nigeria. A Ph.D. Research Proposal, in the Department of Agricultural Economics, University of Nigeria, Nsukka.

World Bank (2001). Nigeria National Fadama Development Program II: Proposal for Project Development Fund (PDF), Block B Grant, Retrieved from: www. gefonline .org.

www.officialwebsitelkogistategovernementlofnigeria.stateagenciesandboardladp. mht retrieved 11th October 2009

http://dx.doi.org/10.4314/jae.v15i1.8 